\title{
KEMAMPUAN KOMUNIKASI MATEMATIS SISWA SMP DITINJAU BERDASARKAN SELF ESTEEM PADA MATERI SISTEM PERSAMAAN LINEAR DUA VARIABEL
}

\author{
Efira Dwitama Ananda \\ Pendidikan Matematika, Fakultas Matematika dan Ilmu Pengetahuan Alam, Universitas Negeri Surabaya \\ Email : efiraananda16030174091@mhs.unesa.ac.id
}

\section{Siti Khabibah}

Pendidikan Matematika, Fakultas Matematika dan Ilmu Pengetahuan Alam, Universitas Negeri Surabaya Email : $\underline{\text { sitikhabibah@unesa.ac.id }}$

\begin{abstract}
Abstrak
Tujuan utama penelitian ini untuk mendeskripsikan kemampuan komunikasi matematis siswa sekolah menengah pertama yang memiliki tipe self esteem tinggi dan tipe self esteem rendah dalam menyelesaikan masalah Sistem Persamaan Linear Dua Variabel. Penelitian ini merupakan penelitian deskriptif kualitatif. Subjek penelitian ini terdiri dari dua orang siswa kelas VIII dengan tingkat self esteem tinggi dan tingkat self esteem rendah yang masing-masing memiliki kesamaan jenis kelamin dan memiliki kemampuan matematika yang setara. Pengumpulan data pada penelitian ini menggunakan tes tingkat self esteem, tes komunikasi matematis tulis, dan wawancara. Sedangkan, teknik analisis data yang digunakan dalam penelitian ini meliputi kondensasi data, penyajian data dan penarikan kesimpulan. Dari hasil penelitian menunjukkan bahwa keakuratan komunikasi matematis tulis siswa dengan tingkat self esteem rendah, yaitu akurat untuk seluruh tahapan pemecahan masalah, sedangkan kelengkapan komunikasi matematis tulis tidak lengkap untuk seluruh tahapan pemecahan masalah terkecuali dalam tahap memahami masalah dan pada tingkat kelancaran komunikasi matematis tulis lancar untuk seluruh tahapan pemecahan masalah. Keakuratan komunikasi matematis lisan siswa dengan tingkat self esteem rendah,yaitu akurat untuk seluruh tahapan pemecahan masalah, sedangkan kelengkapan komunikasi matematis lisan lengkap pada tahap menyusun rencana penyelesaian masalah namun tidak lengkap pada tahap memahami masalah dan menyelesaikan masalah. Pada tingkat kelancaran komunikasi matematis lisan lancar untuk seluruh tahap pemecahan masalah. Keakuratan komunikasi matematis tulis siswa dengan tingkat self esteem tinggi, yaitu akurat untuk penulisan strategi penyelesaian masalah, penulisan langkah penyelesaian masalah, dan perhitungan. Kelengkapan komunikasi matematis tulis tidak lengkap untuk seluruh tahapan pemecahan masalah, sedangkan kelancaran komunikasi matematis tulis lancar pada tahap memahami masalah dan menuliskan strategi penyelesaian masalah. Kemudian untuk keakuratan komunikasi matematis lisan siswa dengan tingkat self esteem tinggi, yaitu akurat pada tahap memahami masalah, menyebutkan istilah atau notasi matematika, menjelaskan langkah-langkah penyelesaian masalah dan perhitungan. Sedangkan kelengkapan komunikasi matematis lisan siswa lengkap hanya pada tahap memahami masalah, selain pada tahap tersebut tidak lengkap. Kelancaran komunikasi matematis lisan siswa lancar pada tahap memahami masalah, menyelesaikan masalah, dan memeriksa kembali.
\end{abstract}

Kata Kunci: kemampuan komunikasi matematis, self esteem, sistem persamaan linear dua variabel

\section{Universitas Abstract}

The main purpose of this research to describe the mathematical communication ability of junior high school students who have high self-esteem and low self-esteem types in solving the Two-Variable Linear Equation System problem. This research is a qualitative descriptive study. The subjects of this study consist of two class VIII students with high self-esteem and low self-esteem, each of whom has the same gender and had equal mathematical abilities. Collecting data in this study using self-esteem level test, written mathematical communication test, and interview. Meanwhile, the data analysis technique used in this study includes data condensation, data presentation and, conclusion drawing The results of the research showed that the accuracy of written mathematical communication of students with low self-esteem is accurate for all stage of problem-solving, while the completeness of written mathematical communication is incompleted for all stages of problem-solving except in the stage of understanding problems and at the level of fluency in written mathematical communication, fluent for all stages of problem-solving. The accuracy of student oral mathematical communication with low esteem accurate for all stages of problem-solving, while the completeness of oral mathematical communication is completed at the stage of preparing problem-solving plans but incompleted at the 
stage of understanding and solving problems. At the fluency level, oral mathematical communication fluent for all stages of problem-solving. The accuracy of students' written mathematical communication with high self-esteem is accurated for writing problem-solving strategies, writing problem-solving steps, and calculations. The completeness of written mathematical communication incompleted for all stages of problem-solving, while the fluency of written mathematical communication fluent at the stage of understanding problems and writing problem-solving strategies. Then for the accuracy of oral mathematical communication students with high self-esteem accurate at the stage of understanding the problem, mentioning mathematical terms or notations, explaining the steps for solving problems and calculations. While the completeness of the student oral mathematical communication is completed only at the stage of understanding the problem, other than stage incompleted. The fluency of students' oral mathematical communication fluent at the stage of understanding problems, solving problems and, checking again.

Keywords: mathematical communication skills, self esteem, system of linear equations in two variables

\section{PENDAHULUAN}

Matematika merupakan salah satu bagian yang penting dalam bidang ilmu pengetahuan. Menurut Cornelius (Abdurrahman, 2003) terdapat lima alasan perlunya belajar matematika, yaitu: (1) sarana berpikir yang jelas dan logis, (2) sarana untuk memecahkan masalah kehidupan sehari-hari, (3) sarana mengenal pola-pola hubungan dan generalisasi pengalaman, (4) sarana untuk mengembangkan kreativitas, dan (5) sarana untuk meningkatkan kesadaran terhadap perkembangan budaya. Karena pentingnya bidang ilmu pengetahuan ini maka pelajaran matematika wajib diberikan pada setiap jenjang. Hal ini diperkuat dengan pernyataan yang dinyatakan dalam UU No. 20 Tahun 2003 tentang Sistem Pendidikan Nasional, Pasal 37 ayat 1 yang menyatakan bahwa "kurikulum pendidikan dasar dan menengah wajib memuat pendidikan matematika" (Lestari, 2013).

Salah satu kemampuan penting yang harus dimiliki oleh siswa dalam pembelajaran matematika ialah kemampuan komunikasi. Hal ini diperkuat oleh National Council of Teacher of Mathematics (2000:29) yang menetapkan lima kemampuan dasar yang dapat diperoleh siswa saat pembelajaran matematika, yaitu: (1) kemampuan pemecahan masalah; (2) kemampuan penalaran dan pembuktian; (3) kemampuan komunikasi; (4) kemampuan koneksi; serta (5) kemampuan representasi. Dari pernyataan diatas maka dapat terlihat bahwa kemampuan komunikasi merupakan salah satu kemampuan penting yang harus dimiliki siswa dalam pembelajaran matematika. Lunenburg (dalam Rais, 2017) menyatakan bahwa komunikasi merupakan suatu proses pemindahan informasi dan pemahaman umum dari satu orang ke lainnya. Melalui sebuah komunikasi maka siswa dapat mendiskusikan pemahaman yang dimiliki dengan guru dan siswa lainnya. National Council of Teachers of Mathematics (NCTM, 2000) menyatakan bahwa komunikasi matematis adalah sebuah cara untuk berbagi ide dan mengklarifikasi pemahaman. Hal ini berarti bahwa dengan adanya komunikasi matematis maka akan membantu siswa dalam memahami materi pembelajaran.

Wardhani dan Rumiati (2011: 16) menyatakan bahwa salah satu aspek kemampuan yang dinilai dalam Program for International Student Assessment (PISA) yang dilaksanakan oleh Organization Economic Cooperation and Development (OECD) adalah komunikasi matematis. Namun, kemampuan komunikasi matematis siswa Indonesia masih tergolong rendah. Organisasi Kerja Sama Ekonomi dan Pembangunan (OECD, 2016) menyatakan hasil Survei Programme for International Student Assessment (PISA) terhadap anak usia 15 tahun pada 2015 menempatkan kemampuan matematika siswa Indonesia pada peringkat 64 dari 72 negara. Pada kategori science, reading, and mathematics untuk memberikan kinerja yang terbaik setidaknya dalam satu mata pelajaran pada level 5 atau 6 maka siswa Indonesia hanya mampu mencapai $0,8 \%$ dari standar PISA 15,3\% dengan rata-rata 386. Hasil PISA 2018 menunjukkan bahwa Indonesia mengalami penurunan rata-rata menjadi 379 (OECD, 2018). Berdasarkan hasil PISA 2015 dan 2018 tersebut maka kemampuan berpikir matematis siswa di Indonesia masih dibawah rata-rata skor PISA dan dapat dikatakan juga bahwa Indonesia masih berada pada level 1. Kemampuan berpikir yang dimaksud pada instrumen PISA tersebut adalah mampu menentukan strategi dari pemecahan masalah, mengkonseptualisasi, menggeneralisasi, menalar, mengkomunikasikan tindakan dan merefleksikan penemuan mereka. Selain itu juga mampu menginterpretasikan dan memberikan argumen. Pencapaian siswa pada soal-soal PISA tersebut dapat digunakan sebagai acuan bahwa kemampuan komunikasi matematis siswa di Indonesia masih tergolong rendah. Sementara itu hasil survei yang dilaksanakan oleh The International Association for The Evaluacition of Education Achievement (IEA) yang mengukur perkembangan matematika dan IPA dalam Trends in International Mathematics and Science Study (TIMSS) 
pada tahun 2015 juga menunjukkan hasil yang sama, yaitu kemampuan matematika siswa di Indonesia masih tergolong rendah. Indonesia memperoleh peringkat 45 dari 50 negara dengan nilai 397 . Sementara rata-rata yang telah ditetapkan adalah 500 maka Indonesia memperoleh nilai dibawah rata-rata (Meisya, Suhandri, \& Nufus, 2018). Dari beberapa hasil penelitian tersebut maka kemampuan komunikasi matematis di Indonesia masih tergolong rendah.

Self-esteem atau kepercayaan diri dapat diartikan sebagai suatu kepercayaan terhadap diri sendiri yang dimiliki setiap individu dalam kehidupannya, serta bagaimana individu tersebut memandang dirinya secara utuh dengan mengacu pada konsep diri (Rakhmat, 2000). Tandiling (2012) menyatakan bahwa belajar dengan kepercayaan diri yang dimiliki dapat berguna dalam mengemukakan gagasan baru sehingga siswa dapat berhasil dalam belajar matematika. Dengan adanya rasa percaya diri, maka siswa dapat mengomunikasikan gagasan atau ide yang dimiliki kepada siswa lainnya dengan lebih berani. Selain itu, Sidik dkk. (2017) menyatakan bahwa semakin tinggi kepercayaan diri seorang individu maka kemampuan komunikasi matematik dalam dirinya akan semakin tinggi pula. Begitupun sebaliknya, semakin rendah kemampuan komunikasi seseorang maka akan semakin rendah pula kepercayaan diri yang dimiliki seorang individu tersebut. Berdasarkan beberapa pernyataan diatas maka selfesteem merupakan salah satu aspek penting yang menunjang dalam pembelajaran.

Sistem Persamaan Linear Dua Variabel merupakan materi yang dipelajari siswa di SMP kelas VIII semester genap. Materi tersebut merupakan materi yang erat hubungannya dengan kehidupan sehari-hari seperti menghitung harga suatu barang. Materi SPLDV merupakan salah satu kompetensi yang harus dikuasai siswa kelas VIII Sekolah Menengah Pertama (SMP) dalam kurikulum 2013. Penelitian ini menggunakan materi tersebut karena nyatanya terdapat siswa yang mengalami kesulitan dalam menyelesaikan permasalahan yang menyangkut Sistem Persamaan Linear Dua Variabel berbentuk soal cerita. Hal tersebut didukung oleh penelitian yang dilakukan Puspitasari, Yusmin, dan Nursangaji (2015) bahwa kesulitan yang dihadapi siswa dalam menyelesaikan soal cerita dengan materi SPLDV adalah kesulitan menentukan dan memisalkan variabel, mengubah soal cerita menjadi bentuk model matematika, kesulitan menggunakan metode eliminasi juga substitusi, siswa juga kesulitan dalam mengoperasikan penjumlahan dan pengurangan, dan juga kesulitan dalam menentukan nilai variabel.

Berdasarkan uraian di atas maka peneliti tertarik untuk meneliti tentang "Kemampuan Komunikasi
Matematis Siswa SMP Ditinjau Berdasarkan Self Esteem Pada Materi Persamaan Linear Dua Variabel". Penelitian ini akan mendeskripsikan kemampuan siswa yang memiliki self-esteem tinggi dan self-esteem rendah dalam mengomunikasikan ide-ide matematis

\section{METODE}

Pendekatan yang digunakan dalam penelitian ini adalah deskriptif kualitatif. Semiawan (2010) menyatakan bahwa penelitian kualitatif merupakan metode yang digunakan untuk mencari pengetahuan atau gambaran mengenai suatu gelaja, fakta atau realita. Bogdan dan Taylor (dalam Moleong, 2016) menyatakan bahwa metodologi kualitatif merupakan prosedur atau tahap penelitian yang menghasilkan data deskriptif berupa katakata tertulis atau lisan dari orang-orang dan perilaku yang diamati. Dengan demikian penelitian ini akan menggambarkan sebuah fakta atau realita berupa katakata tertulis atau lisan dari objek penelitian berdasarkan fakta yang ada dan mencoba untuk menganalisis kebenaran berdasarkan data-data yang diperoleh. Pengumpulan data pada penelitian ini terdiri dari tes skala self esteem, tes komunikasi matematis tulis, dan wawancara. Tes skala self esteem dalam penelitian ini terdiri dari 10 soal yang diadopsi dari Azwar (2015:5). Tes skala self esteem bertujuan untuk menentukan tingkat self esteem siswa. Sedangkan tes komunikasi matematis tulis bertujuan untuk mendeskripsikan kemampuan komunikasi matematis secara tertulis. Wawancara dilakukan pada tahap terakhir yang bertujuan untuk memperoleh informasi komunikasi matematis lisan pada siswa.

Siswa dalam penelitian ini merupakan siswa kelas VIII-E SMPN 44 Surabaya yang terdiri dari satu kelas. Keseluruhan siswa akan melaksanakan pengisian tes skala self esteem. Kemudian dilakukan penggolongan dari hasil tes skala self esteem sehingga diperoleh siswa dengan tingkat self esteem tinggi dan rendah. Penentuan subjek penelitian ini dipilih 2 orang siswa yang memiliki tingkat self esteem berbeda, yaitu tinggi dan rendah dengan masing-masing subjek memiliki kesamaan jenis kelamin dan memiliki kemampuan matematika yang setara. Jenis kelamin dan kemampuan matematika dapat mempengaruhi penyelesaian masalah matematika siswa. Cahyono (2017) menyatakan bahwa faktor internal yang mempengaruhi kemampuan pemecahan masalah siswa adalah kecerdasan, motivasi, minat, bakat, kemampuan matematika maupun perbedaan jenis kelamin. Setelah penentuan subjek dilakukan maka subjek tersebut akan melakukan tes kemampuan komunikasi matematis tulis beserta wawancara hasil pengerjaan tes komunikasi matematis tulis yang telah dilakukan. 
Teknik analisis data yang digunakan dalam penelitian ini merupakan analisis interaktif menurut Miles, Huberman, dan Saldana. Menurut Miles, Huberman, dan Saldana (2014) menyatakan bahwa aktivitas dalam analisis data kualitatif dilakukan secara interaktif dan berlangsung secara terus-menerus hingga tuntas. Aktivitas analisis data dalam penelitian ini terdiri dari kondensasi data, menyajikan data, dan menarik simpulan atau verifikasi. Tahap kondensasi data dalam penelitian ini diuraikan sebagai berikut, yaitu

1. Kondensasi data hasil tes skala self esteem

Menganalisis data hasil tes skala self esteem bertujuan untuk menentukan tingkat self esteem siswa. Penentuan tingkat self esteem siswa pada penelitian ini menggunakan alat ukur Rosenberg Self Esteem Scale (RSES). Alat ukur ini terdiri dari 10 bagian dan merupakan alat ukur unidimensional yang mengukur self esteem secara global (Schmitt $\&$ Allik, 2005). Pada alat ukur ini bentuk skala yang digunakan untuk menentukan nilai self esteem siswa berupa skala respon atau skala likert. Pada skala self esteem terdapat beberapa pernyataan favorable dan unfavorable. Pernyataan favorable merupakan pernyataan yang berisi halhal positif atau mendukung obyek sikap, sedangkan pernyataan unfavorable merupakan pernyataan yang berisi hal-hal yang negatif atau tidak mendukung obyek sikap yang hendak diungkap. Pilihan alternatif jawaban dan penilaian untuk setiap pernyataan dalam skala self esteem bergerak antara 0 hingga dengan 4 untuk pernyataan favorable dan berlaku sebaliknya untuk pernyataan unfavorable (Azwar, 2015: 73). Susunan penilaian skala self esteem terlihat pada tabel dibawah ini.

Tabel 1. Susunan Penilaian Skala Self Esteem

\begin{tabular}{|l|c|c|}
\hline \multicolumn{1}{|c|}{ Kategori Jawaban } & Favorable & Unfavorable \\
\hline STS (Sangat Tidak Sesuai) & 0 & 4 \\
\hline TS (Tidak Sesuai) & 1 & 3 \\
\hline E (Antara Sesuai dan Tidak) & 2 & 2 \\
\hline S (Sesuai) & 3 & 1 \\
\hline SS (Sangat Sesuai) & 4 & 0 \\
\hline
\end{tabular}

2. Kondensasi data hasil tes komunikasi matematis tulis

Data hasil tes komunikasi matematis dianalisis dengan menggunakan kunci jawaban yang telah ditentukan sebelumnya. Kemudian peneliti akan mendeskripsikan komunikasi matematis siswa secara tertulis dengan menggunakan indikator komunikasi matematis. Indikator komunikasi matematis dalam penelitian ini mengadaptasi dari penelitian Dewi (2009) yang terdiri dari keakuratan, kelengkapan, dan kelancaran komunikasi matematis.

Tabel 1. Indikator Keakuratan Komunikasi Matematis Siswa

\begin{tabular}{|c|c|c|}
\hline No & $\begin{array}{c}\text { Komunikasi Matematis } \\
\text { Tulis }\end{array}$ & $\begin{array}{c}\text { Komunikasi Matematis } \\
\text { Lisan }\end{array}$ \\
\hline 1 & $\begin{array}{l}\text { Penyampaian hal-hal yang } \\
\text { relevan dengan masalah } \\
\text { dikatakan akurat apabila } \\
\text { subjek menuliskan hal-hal } \\
\text { yang relevan dengan } \\
\text { masalah. }\end{array}$ & $\begin{array}{lr}\text { Penyampaian } & \text { hal-hal } \\
\text { yang relevan dengan } & \text { subjek } \\
\text { masalah dikatakan akurat } \\
\text { apabila } \\
\text { mengucapkan atau } \\
\text { menyatakan hal-hal yang } \\
\text { relevan dengan masalah } \\
\text { secara tepat. }\end{array}$ \\
\hline 2 & $\begin{array}{l}\text { Syarat atau rumus yang } \\
\text { akan digunakan dikatakan } \\
\text { akurat apabila subjek } \\
\text { menuliskan syarat atau } \\
\text { rumus sesuai dengan } \\
\text { kaidah matematika dan } \\
\text { sesuai dengan kriteria (1). }\end{array}$ & $\begin{array}{l}\text { Syarat atau rumus yang } \\
\text { digunakan dikatakan } \\
\text { akurat apabila subjek } \\
\text { mengucapkan atau } \\
\text { menyatakan syarat atau } \\
\text { rumus yang digunakan } \\
\text { dengan benar menurut } \\
\text { kaidah matematika dan } \\
\text { sesuai dengan kriteria (1). }\end{array}$ \\
\hline 3 & $\begin{array}{l}\text { Perhitungan dikata } \\
\text { akurat apabila sub } \\
\text { menuliskan langk } \\
\text { langkah perhitungan y } \\
\text { dibutuhkan dengan be } \\
\text { sesuai dengan rur } \\
\text { kriteria (2). }\end{array}$ & $\begin{array}{lr}\text { Perhitungan dikatakan } \\
\text { akurat jika } \\
\text { mengucapkan } \\
\text { menyatakan atau } \\
\text { langkah perhitungan yang } \\
\text { dibutuhkan dengan benar } \\
\text { sesuai dengan rumus } \\
\text { yang diberikan pada } \\
\text { kriteria (2). }\end{array}$ \\
\hline
\end{tabular}

Tabel 2. Indikator Kelengkapan Komunikasi Matematis Siswa

\begin{tabular}{|c|c|c|}
\hline No & & $\begin{array}{c}\text { Komunikasi Matema } \\
\text { Lisan }\end{array}$ \\
\hline 1 & $\begin{array}{l}\text { Penyampaian hal-hal yang } \\
\text { relevan dengan } \\
\text { permasalahan dikatakan } \\
\text { lengkap apabila subjek } \\
\text { menulis tentang hal-hal } \\
\text { yang relevan dengan } \\
\text { permasalahan telah } \\
\text { memadai } \\
\text { menyelesaikan } \\
\text { permasalahan tersebut. }\end{array}$ & $\begin{array}{lr}\text { Penyampaian hal-hal } \\
\text { yang relevan dengan } \\
\text { masalah dikatakan } \\
\text { lengkap apabila subjek } \\
\text { mengucapkan atau } \\
\text { menyatakan hal-hal yang } \\
\text { relevan dengan } \\
\text { permasalahan telah } \\
\text { memadai dalam } \\
\text { penyelesaian masalah. }\end{array}$ \\
\hline & $\begin{array}{l}\text { Syarat atau rumus yang } \\
\text { akan digunakan dapat } \\
\text { dikatakan lengkap apabila } \\
\text { subjek menulis syarat atau } \\
\text { rumus yang akan } \\
\text { digunakan cukup dalam } \\
\text { menyelesaikan } \\
\text { permasalahan. }\end{array}$ & $\begin{array}{lr}\text { Syarat atau rumus yang } \\
\text { akan } & \text { digunakan } \\
\text { dikatakan } & \text { lengkap } \\
\text { apabila } & \text { subjek } \\
\text { mengucapkan } & \text { atau } \\
\text { menyatakan } & \text { syarat atau } \\
\text { rumus yang } & \text { dibutuhkan } \\
\text { memadai } & \text { untuk } \\
\text { penyelesaian masalah. }\end{array}$ \\
\hline 3 & $\begin{array}{l}\text { Perhitungan dikatakan } \\
\text { lengkap apabila subjek } \\
\text { menulis langkah-langkah } \\
\text { atau tahap perhitungan } \\
\text { yang dibutuhkan cukup } \\
\text { untuk menyelesaikan } \\
\text { permasalahan. }\end{array}$ & $\begin{array}{l}\text { Perhitungan dikatakan } \\
\text { lengkap apabila subjek } \\
\text { mengucapkan atau } \\
\text { menyatakan langkah- } \\
\text { langkah perhitungan } \\
\text { yang dibutuhkan cukup } \\
\text { untuk menyelesaikan } \\
\text { masalah. }\end{array}$ \\
\hline
\end{tabular}


Komunikasi matematis dikatakan lengkap apabila informasi yang disampaikan cukup untuk menyelesaikan masalah. Dalam menyelesaikan masalah yang diberikan dalam penelitian ini akan menggunakan langkah-langkah penyelesaian masalah menurut Polya.

Kelancaran merupakan indikator yang tidak kalah penting dengan aspek keakuratan dan kelengkapan. Hal tersebut dikarenakan tanpa adanya kelancaran dalam komunikasi maka informasi yang diperoleh tidak akan sempurna. Kelancaran komunikasi matematis adalah sejauh mana seorang individu menyampaikan informasi sampai pada tujuan akhir dengan batas waktu yang telah ditentukan.

Tabel 3. Indikator Kelancaran Komunikasi Matematis Siswa

\begin{tabular}{|c|c|c|}
\hline No & $\begin{array}{c}\text { Komunikasi } \\
\text { Matematis Tulis }\end{array}$ & $\begin{array}{c}\text { Komunikasi Matematis } \\
\text { Lisan }\end{array}$ \\
\hline 1 & $\begin{array}{l}\text { Siswa tidak terhenti atau } \\
\text { lancar ketika } \\
\text { menuliskan } \\
\text { penyelesaian masalah } \\
\text { sehingga informasi yang } \\
\text { diberikan sampai pada } \\
\text { tujuan akhir dalam batas } \\
\text { waktu yang telah } \\
\text { ditentukan. }\end{array}$ & $\begin{array}{l}\text { Siswa tidak terhenti atau } \\
\text { lancar ketika } \\
\text { menyampaikan } \\
\text { penyelesaian masalah } \\
\text { sehingga informasi yang } \\
\text { diberikan sampai pada } \\
\text { tujuan akhir dalam batas } \\
\text { waktu yang telah } \\
\text { ditentukan. }\end{array}$ \\
\hline
\end{tabular}

3. Kondensasi data hasil wawancara

Metode analisis data yang digunakan untuk mengetahui data hasil wawancara adalah (1) meminta siswa untuk menjelaskan penyelesaian tes komunikasi matematis tulis yang telah dikerjakan secara lisan; (2) selama siswa menjelaskan penyelesaian tes komunikasi matematis tulis secara lisan maka peneliti merekam seluruh ucapan siswa; (3) menuliskan hasil wawancara siswa dan menyesuaikan dengan rekaman agar hasilnya sesuai; (4) mentranskrip hasil wawancara siswa dalam bentuk tulisan; (5) mendeskripsikan hasil wawancara siswa berdasarkan hasil analisis tes dan wawancara yang telah disesuaikan dengan indikator kemampuan komunikasi matematis siswa sehingga dapat diketahui kemampuan komunikasi matematis siswa.

Penyajian data yang sering digunakan dalam penelitian kualitatif adalah teks naratif. Miles dan Huberman (dalam Sugiyono, 2013: 341) menyatakan bahwa "the most frequent form of display data for qualitative research data in the past has been narrative text". Penyajian data ini dapat memudahkan untuk memahami apa yang terjadi dan menjawab pertanyaan penelitian. Penjabaran penyajian data dalam penelitian ini adalah (1) menyajikan hasil tes skala self esteem siswa bertujuan untuk mengetahui penggolongan siswa dengan self esteem tinggi dan rendah; (2) menyajikan hasil tes komunikasi matematis tulis siswa berdasarkan tingkat self esteem; (3) menyajikan hasil wawancara siswa yang telah direkam; (4) menyajikan hasil analisis berupa gambaran dalam pemecahan masalah matematika berdasarkan tingkat self esteem siswa. Tahap terakhir dalam analisis data adalah penarikan kesimpulan. Penarikan kesimpulan dalam penelitian ini meliputi hasil tes skala penggolongan self esteem, hasil tes komunikasi matematis tulis dan wawancara. Penarikan kesimpulan dalam penelitian ini berfungsi untuk menjawab pertanyaan penelitian.

\section{HASIL DAN PEMBAHASAN}

Pada tahap ini akan disajikan hasil penelitian dan pembahasan tentang kemampuan komunikasi matematis siswa SMP ditinjau berdasarkan self esteem pada materi persamaan linear dua variabel. Penelitian ini akan mendeskripsikan kemampuan siswa yang memiliki selfesteem tinggi dan self-esteem rendah dalam mengomunikasikan ide-ide matematis.

\section{Penggolongan Skala Self Esteem}

Tes skala self esteem diberikan kepada siswa di kelas VIII E SMPN 44 Surabaya. Siswa yang telah melakukan pengisian tes skala self esteem berjumlah 28 siswa. Pengisian tes dilaksanakan pada Jumat tanggal 15 Oktober 2020 pada pukul 10.25 dengan menggunakan google forms. Pemilihan waktu sesuai dengan saran guru wali kelas VIII E. Tes skala self esteem memuat 10 butir pernyataan yang digunakan untuk menentukan tingkat self esteem siswa. Setelah melakukan penilaian skor siswa maka langkah selanjutnya adalah melakukan penggolongan tingkat self esteem siswa. Langkah-langkah untuk melakukan penggolongan tingkat self esteem siswa menjadi dua kategori diadopsi dari Azwar (2015). Data hasil penggolongan tingkat self esteem disajikan sebagai berikut.

Tabel 4. Data Penggolongan Tingkat Self Esteem

\begin{tabular}{|c|c|c|c|}
\hline No & $\begin{array}{c}\text { Nama } \\
\text { Siswa }\end{array}$ & Skor & $\begin{array}{c}\text { Tingkat Self } \\
\text { Esteem }\end{array}$ \\
\hline 1 & FSB & 10 & Rendah \\
\hline 2 & AAR & 11 & Rendah \\
\hline 3 & IPD & 16 & Rendah \\
\hline 4 & JIM & 18 & Rendah \\
\hline 5 & AJD & 19 & - \\
\hline 6 & DAP & 19 & - \\
\hline 7 & NSR & 19 & - \\
\hline 8 & AF & 21 & - \\
\hline 9 & AJC & 23 & - \\
\hline 10 & CSP & 23 & - \\
\hline 11 & GKR & 23 & - \\
\hline 12 & MER & 23 & - \\
\hline
\end{tabular}




\begin{tabular}{|c|c|c|c|}
\hline 13 & RA & 23 & - \\
\hline 14 & AFI & 24 & - \\
\hline 15 & DNA & 24 & - \\
\hline 16 & MZ & 24 & - \\
\hline 17 & NFR & 24 & - \\
\hline 18 & MDA & 25 & - \\
\hline 19 & MBR & 26 & - \\
\hline 20 & AAH & 27 & - \\
\hline 21 & ANA & 27 & - \\
\hline 22 & MA & 27 & - \\
\hline 23 & RPA & 28 & - \\
\hline 24 & FK & 29 & Tinggi \\
\hline 25 & AMD & 30 & Tinggi \\
\hline 26 & JDF & 32 & Tinggi \\
\hline 27 & EAB & 34 & Tinggi \\
\hline 28 & MLR & 36 & Tinggi \\
\hline
\end{tabular}

Berdasarkan hasil penggolongan tingkat self esteem diatas maka diperoleh 4 siswa dengan tingkat self esteem rendah dan 5 siswa dengan tingkat self esteem tinggi.

\section{Penentuan Subjek Penelitian}

Setelah melakukan penggolongan tingkat self esteem maka diperoleh 4 siswa dengan tingkat self esteem rendah dan 5 siswa dengan tingkat self esteem tinggi, kemudian tahap selanjutnya adalah penentuan subjek penelitian. Penentuan subjek penelitian ini terdiri dari dua siswa dengan kemampuan matematika yang setara dan memiliki kesamaan jenis kelamin dengan tingkat self esteem yang berbeda, yaitu tinggi dan rendah. Pemilihan siswa dengan kemampuan matematika yang setara dipilih berdasarkan nilai sumatif siswa yang terdiri dari penilaian harian $(\mathrm{PH})$, tugas (T) dan penilaian tengah semester (PTS). Berdasarkan beberapa kriteria tersebut maka diperoleh subjek penelitian sebagai berikut.

Tabel 5. Penentuan Subjek Penelitian

\begin{tabular}{|c|c|c|c|c|c|c|}
\hline $\begin{array}{c}\text { Nama } \\
\text { Siswa }\end{array}$ & $\begin{array}{c}\text { Jenis } \\
\text { Kelamin }\end{array}$ & PH & T & PTS & $\begin{array}{c}\text { Rata- } \\
\text { Rata }\end{array}$ & $\begin{array}{c}\text { Self } \\
\text { Esteem }\end{array}$ \\
\hline FSB & Perempuan & 80 & 70 & 75 & 75 & Rendah \\
\hline AAR & Perempuan & 75 & 70 & 55 & 66.67 & Rendah \\
\hline IPD & Laki-Laki & 80 & 70 & 70 & 73.33 & Rendah \\
\hline JIM & Perempuan & 60 & 70 & 60 & 63.33 & Rendah \\
\hline FK & Perempuan & 55 & 80 & 70 & 68.33 & Tinggi \\
\hline AMD & Laki-Laki & 45 & 70 & 85 & 66.67 & Tinggi \\
\hline JDF & Perempuan & 70 & 80 & 65 & 71.67 & Tinggi \\
\hline EAB & Perempuan & - & 85 & 55 & - & Tinggi \\
\hline MLR & Laki-Laki & 35 & 70 & - & - & Tinggi \\
\hline
\end{tabular}

Dari tabel tersebut terlihat bahwa subjek penelitian yang memenuhi kriteria yang telah ditentukan diatas adalah AAR dan FK.

\section{Hasil dan Analisis Data Tes Komunikasi Matematis}

Tes komunikasi matematis siswa diberikan kepada dua subjek yang terdiri dari subjek dengan tingkat self esteem tinggi dan subjek dengan tingkat self esteem rendah. Tes komunikasi matematis tulis dan wawancara dilaksanakan pada hari Selasa tanggal 27 Oktober 2020 pukul 10.1512.15 di SMPN 44 Surabaya. Berikut ini akan disajikan hasil dan analisis data komunikasi matematis subjek dengan tingkat self esteem tinggi dan subjek dengan tingkat self esteem rendah.

1. Hasil dan Analisis Data Komunikasi Matematis Tulis Subjek AAR dalam Pemecahan Masalah Matematika

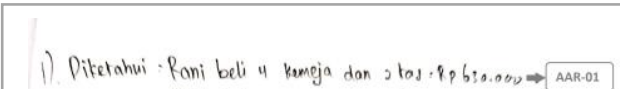

$$
\begin{aligned}
& \text { Andi beli, thengla dan } 3 \text { tos }=P_{P .520 .000} \Rightarrow \text { AAR.02 }
\end{aligned}
$$

Analisis data komunikasi matematis tulis subjek AAR dalam pemecahan masalah matematika sebagai berikut.

\section{Tahap Memahami Masalah}

Berdasarkan data hasil penyelesaian masalah pada gambar 1 maka dapat dianalisis komunikasi matematis tulis subjek AAR dalam tahap memahami masalah matematika sebagai berikut.

\section{Keakuratan}

Subjek AAR telah menuliskan hal-hal yang diketahui dan ditanyakan dalam soal dengan tepat, ditunjukkan pada kode AAR-01, AAR-02, dan AAR-03. Hal-hal atau informasi yang dituliskan subjek pada tahap ini telah relevan atau sesuai dengan soal.

\section{Kelengkapan}

Subjek AAR telah menuliskan seluruh informasi yang diketahui dan ditanyakan dalam soal pada tahap ini.

\section{Kelancaran}

Subjek AAR telah menuliskan seluruh informasi yang diketahui dan ditanyakan dalam soal dengan lancar tanpa ada koreksian pada pekerjaan tulisnya.

\section{Tahap Menyusun Rencana Penyelesaian Masalah}

Berdasarkan data hasil penyelesaian masalah pada gambar 1 maka dapat dianalisis komunikasi matematis tulis subjek AAR dalam tahap menyusun rencana penyelesaian masalah matematika sebagai berikut.

Keakuratan 
Subjek AAR telah menuliskan informasi lain yang digunakan dalam menyelesaikan soal, subjek AAR telah memisalkan harga satu buah kemeja dengan variabel $\mathrm{x}$ dan harga satu buah tas dengan variabel $\mathrm{y}$. Hal tersebut ditunjukkan pada kode AAR-04. Subjek AAR juga telah menuliskan model matematika yang diperoleh dari sebuah informasi pada soal, ditunjukkan pada kode AAR-04. Dalam penyelesaian masalah pada gambar 1 terlihat bahwa subjek AAR menggunakan metode eliminasi untuk menentukan harga satu buah tas. Hal tersebut ditunjukkan pada kode AAR-04. Setelah itu, subjek AAR menentukan harga satu buah kemeja. Ditunjukkan pada kode AAR-05. Pada gambar 1 terlihat bahwa subjek AAR telah menggunakan cara yang tepat untuk menyelesaikan masalah tersebut.

\section{Kelengkapan}

Subjek AAR telah menuliskan rencana yang dibutuhkan untuk penyelesaian masalah, yaitu dengan menuliskan seluruh persamaan yang diperoleh dari soal. Kemudian subjek AAR juga telah memisalkan harga satu tas dengan variabel y dan harga satu kemeja dengan variabel x. Selain itu, subjek AAR menggunakan metode eliminasi dalam penyelesaian masalah tersebut. Hal tersebut ditunjukkan pada kode AAR-04. Akan tetapi, subjek AAR tidak menuliskan istilah atau nama metode yang digunakan dalam penyelesaian masalah tersebut. Selain itu, subjek AAR tidak memaparkan persamaan yang diperoleh dari soal terlebih dahulu, namun persamaan yang diperoleh langsung digunakan pada metode eliminasi. Hal tersebut ditunjukkan pada kode AAR-04. Dari beberapa pemaparan diatas maka subjek AAR belum cukup lengkap dalam penyusunan rencana untuk menyelesaikan masalah tersebut.

\section{Kelancaran}

Pada tahap ini subjek AAR telah menuliskan seluruh rencana yang akan digunakan dalam penyelesaian masalah dengan lancar tanpa tersendat-sendat dan tidak terdapat bekas coretan atau koreksian pada lembar jawaban subjek AAR. Hal tersebut ditunjukkan pada kode AAR-01, AAR-02, AAR03 dan AAR-04.

\section{Tahap Menyelesaikan Masalah}

Berdasarkan data hasil penyelesaian masalah pada gambar 1 maka dapat dianalisis kemampuan komunikasi matematis tulis subjek AAR dalam menyelesaikan masalah matematika sebagai berikut.

\section{Keakuratan}

Langkah awal yang dilakukan subjek AAR dalam menyelesaikan masalah tersebut adalah menuliskan seluruh informasi yang diketahui dan ditanyakan pada soal. Hal tersebut ditunjukkan pada kode AAR-01, AAR-02, dan AAR-03. Kemudian langkah kedua subjek AAR menuliskan persamaan-persamaan yang diperoleh dari soal. Persamaan tersebut mencakup variabel $\mathrm{x}$ dan y yang berfungsi sebagai permisalan harga satu buah kemeja dan harga satu buah tas. Kemudian subjek AAR melakukan tahap eliminasi yang digunakan untuk menentukan nilai variabel $\mathrm{y}$. Variabel y pada penyelesaian tersebut merupakan permisalan dari harga satu buah tas. Ditunjukkan pada kode AAR-04. Kemudian langkah ketiga, subjek AAR menentukan nilai variabel $\mathrm{x}$ yang dimisalkan sebagai harga satu buah kemeja. Ditunjukkan pada kode AAR-05. Setelah mendapatkan nilai dari $\mathrm{x}$ dan y yang merupakan harga satu buah kemeja dan tas maka subjek AAR membuat perkiraan barang apa yang dapat dibeli Ana dengan uang yang tertera pada soal tersebut. Langkah terakhir, subjek AAR menentukan dua jenis barang yang dapat dibeli oleh Ana. Hal tersebut ditunjukkan pada kode AAR-08 dan AAR-09. Dalam menyelesaikan masalah, subjek AAR telah melakukan perhitungan yang tepat.

\section{Kelengkapan}

Subjek AAR telah menuliskan langkah-langkah yang dibutuhkan untuk menyelesaikan masalah tersebut, yaitu dengan mengubah informasi yang diketahui menjadi sebuah persamaan. Kemudian melakukan tahap eliminasi untuk menentukan variabel y yang merupakan harga satu buah tas. Hal tersebut ditunjukkan pada kode AAR-04. Setelah itu menentukan nilai variabel $\mathrm{x}$ atau harga dari satu buah kemeja. Namun, subjek AAR tidak memaparkan cara untuk menentukan nilai dari variabel x. Subjek AAR hanya menuliskan hasil dari perhitungan yang telah dilakukan. Ditunjukkan pada kode AAR-05. Hal tersebut menunjukkan bahwa subjek AAR dapat menyelesaikan masalah tersebut dengan tepat akan tetapi, subjek AAR kurang lengkap dalam memaparkan tahap-tahap penyelesaian masalah tersebut.

\section{Kelancaran}

Subjek AAR telah menuliskan seluruh tahap-tahap penyelesaian masalah dengan lancar. Hal tersebut dikarenakan tidak terdapat coretan atau koreksian pada lembar jawaban subjek AAR. Ditunjukkan pada kode AAR-04, AAR-05, AAR-06,AAR-07, AAR-08, dan AAR-09.

\section{Tahap Memeriksa Kembali}

Berdasarkan data hasil penyelesaian masalah pada gambar 1 maka dapat dianalisis kemampuan 
komunikasi matematis tulis subjek AAR dalam tahap memeriksa kembali sebagai berikut.

\section{Keakuratan}

Subjek AAR telah menuliskan kesimpulan dari permasalahan yang telah diselesaikan dengan tepat. Hal tersebut ditunjukkan pada kode AAR-09

\section{Kelancaran}

Subjek AAR telah menyelesaikan persoalan yang diberikan dengan lancar tanpa tersendat-sendat, tidak terdapat bekas coretan atau koreksian dan penyelesaian masalah sesuai dengan batas waktu yang telah ditentukan yaitu 30 menit.

\section{Hasil dan Analisis Data Komunikasi Matematis} Tulis Subjek FK dalam Pemecahan Masalah Matematika

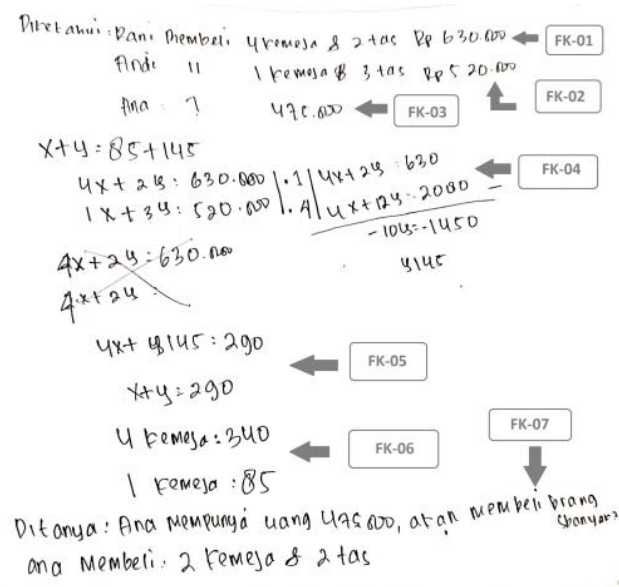

Ditanya: Ana mempunya uang 475000 , at an membeli brang ana Membeli: 2 remeja \& 2 tas

Gambar 2. Hasil Penyelesaian Tes Komunikasi Matematis Tulis Subjek FK

Analisis data komunikasi matematis tulis subjek FK dalam pemecahan masalah matematika sebagai berikut.

\section{Tahap Memahami Masalah}

Berdasarkan data penyelesaian masalah pada gambar 2 maka dapat dianalisis kemampuan komunikasi matematis tulis subjek FK dalam tahap memahami masalah matematika sebagai berikut.

\section{Keakuratan}

Subjek FK telah menuliskan informasi yang diketahui pada soal. Namun subjek FK tidak menuliskan hal apa yang ditanyakan pada soal tersebut. Ditunjukkan pada kode FK-01, FK-02, dan FK-03. Dapat dikatakan subjek FK belum cukup akurat dalam tahap memahami masalah karena subjek FK tidak dapat menuliskan pertanyaan yang sesuai atau relevan dengan masalah atau soal tersebut.

\section{Kelengkapan}

Subjek FK telah menuliskan seluruh informasi yang diketahui pada soal. Ditunjukkan pada kode FK-01 dan FK-02. Akan tetapi, subjek FK tidak menuliskan apa yang ditanyakan pada soal. Hal tersebut ditunjukkan pada kode FK-03 sehingga dapat dikatakan pada tahap memahami masalah subjek FK belum cukup lengkap dalam menuliskan seluruh informasi yang dibutuhkan.

\section{Kelancaran}

Subjek FK telah menuliskan seluruh informasi yang diketahui pada soal tanpa tersendat-sendat atau dapat dikatakan lancar. Hal tersebut dikarenakan tidak terdapat bekas coretan atau koreksian pada pekerjaan tulisnya.

\section{Tahap Menyusun Rencana Penyelesaian Masalah}

Berdasarkan data penyelesaian masalah pada gambar 2 maka dapat dianalisis komunikasi matematis tulis subjek FK dalam tahap menyusun rencana penyelesaian masalah matematika sebagai berikut.

\section{Keakuratan}

Subjek FK menuliskan informasi lain yang dibutuhkan dalam menyelesaikan soal, subjek FK menuliskan persamaan-persamaan yang diperoleh dari soal. Kemudian subjek FK menggunakan metode eliminasi untuk menentukan nilai variabel y yang merupakan permisalan dari harga sebuah tas. Hal tersebut ditunjukkan pada kode FK-04. Subjek FK telah menentukan nilai variabel $\mathrm{x}$ atau harga sebuah kemeja yang ditunjukkan pada kode FK-06.

Berdasarkan uraian diatas maka subjek FK telah menggunakan metode yang tepat dalam penyelesaian masalah tersebut. Akan tetapi, subjek FK tidak menuliskan istilah atau nama metode yang digunakan dalam penyelesaian tersebut. Hal tersebut ditunjukkan pada kode FK-04 dan FK-06.

\section{Kelengkapan}

Subjek FK telah menuliskan rencana untuk penyelesaian masalah, yaitu dengan menggunakan metode eliminasi untuk penentuan nilai variabel y yang merupakan harga dari sebuah tas. Ditunjukkan pada kode FK-04. Kemudian menentukan nilai variabel $\mathrm{x}$ atau harga dari sebuah kemeja ditunjukkan pada kode FK-06. Akan tetapi, subjek FK tidak menuliskan istilah atau nama metode yang digunakan dalam penyelesaian masalah tersebut. Selain itu, subjek FK tidak memaparkan persamaan yang diperoleh dari soal terlebih dahulu, namun persamaan yang diperoleh langsung digunakan pada metode eliminasi. Hal tersebut ditunjukkan pada kode FK-04. Dari beberapa pemaparan diatas maka subjek FK belum cukup lengkap dalam penyusunan rencana untuk menyelesaikan masalah tersebut.

\section{Kelancaran}

Pada tahap ini subjek FK belum cukup lancar dalam menyusun rencana penyelesaian masalah. Hal 
tersebut dikarenakan terdapat sebuah persamaan yang tidak jelas dalam penyelesaian masalah tersebut. Pernyataan tersebut ditunjukkan antara kode FK-03 dan FK-04.

\section{Tahap Menyelesaikan Masalah}

Berdasarkan data penyelesaian masalah pada gambar 2 maka dapat dianalisis komunikasi matematis tulis subjek FK dalam tahap menyelesaikan masalah matematika sebagai berikut.

\section{Keakuratan}

Langkah awal yang dilakukan subjek FK dalam penyelesaian masalah tersebut adalah menuliskan seluruh informasi yang diketahui pada soal. Kemudian menuliskan seluruh persamaan yang telah diperoleh pada soal. Persamaan-persamaan tersebut digunakan pada tahap eliminasi untuk menentukan nilai variabel y atau harga dari sebuah tas. Ditunjukkan pada kode FK-04. Kemudian menentukan nilai variabel $\mathrm{x}$ atau harga dari sebuah kemeja yang ditunjukkan pada kode FK-06. Langkah terakhir, subjek FK menarik kesimpulan tentang barang apa yang dapat dibeli oleh Ana. Hal tersebut ditunjukkan pada kode FK-07.

\section{Kelengkapan}

Pada tahap ini subjek FK telah menuliskan beberapa langkah yang digunakan untuk menyelesaikan permasalahan tersebut, yaitu dengan menuliskan seluruh persamaan yang diperoleh dari soal. Kemudian menggunakan metode eliminasi untuk menentukan nilai variabel y atau harga dari sebuah tas. Dari perolehan nilai variabel y maka dapat ditentukan nilai variabel $\mathrm{X}$. Subjek FK telah memaparkan cara yang digunakan untuk menentukan nilai dari variabel $\mathrm{x}$, namun kurang tepat dalam menuliskan persamaan. Hal tersebut ditunjukkan pada kode FK-05. Meskipun demikian, subjek FK dapat menentukan nilai dari variabel $\mathrm{x}$ dengan tepat. Hal tersebut ditunjukkan pada kode FK-06. Berdasarkan uraian diatas maka subjek FK belum cukup lengkap atau kurang lengkap dalam menuliskan langkah-langkah yang dibutuhkan untuk menyelesaikan masalah tersebut. Karena tidak memaparkan cara yang tepat dalam penentuan nilai variabel $\mathrm{x}$.

\section{Kelancaran}

Subjek FK dalam tahap ini belum cukup lancar dalam menuliskan seluruh langkah-langkah penyelesaian masalah. Hal tersebut ditunjukkan antara kode FK-03 dan FK-04 terdapat persamaan yang tidak dibutuhkan dan tidak jelas penggunaannya. Selain itu, pada kode FK-05 juga menunjukkan hal yang serupa. Pada pekerjaan tulis subjek FK terdapat bekas coretan atau koreksian. Dari beberapa uraian diatas menunjukkan bahwa subjek FK kurang lancar dalam menuliskan langkah atau tahapan penyelesaian masalah matematika tersebut.

\section{Tahap Memeriksa Kembali}

Berdasarkan data penyelesaian masalah pada gambar 2 maka dapat dianalisis kemampuan komunikasi matematis tulis subjek FK dalam tahap memeriksa kembali sebagai berikut.

\section{Keakuratan}

Pada tahap ini subjek FK kurang tepat dalam menuliskan kesimpulan dari penyelesaian masalah tersebut. Hal tersebut terlihat pada kode FK-07 yang menunjukkan bahwa terdapat kata ditanya pada penarikan kesimpulan tersebut.

\section{Kelancaran}

Subjek FK dalam penyelesaian permasalahan tersebut kurang lancar atau tersendat-sendat. Hal tersebut ditunjukkan pada lembar jawaban subjek FK yang terdapat bekas coretan atau koreksian. Selain itu, dalam penyelesaian masalah tersebut subjek FK melebihi batas waktu yang telah ditentukan.

\section{Hasil dan Analisis Data Hasil Tes Wawancara}

Agar mempermudah dalam menyajikan informasi hasil wawancara antara peneliti dan subjek penelitian maka akan digunakan kode penyajian hasil wawancara sebagai berikut.

Tabel 6. Kode Penyajian Hasil Wawancara

\begin{tabular}{|c|c|}
\hline Kode & Keterangan \\
\hline P-x & Pertanyaan ke-x yang akan disampaikan oleh peneliti \\
\hline Si-x & $\begin{array}{c}\text { Jawaban lisan yang disampaikan oleh subjek dengan } \\
\text { urutan ke-x dan i merupakan inisial nama subjek }\end{array}$ \\
\hline
\end{tabular}

1. Hasil dan Analisis Data Komunikasi Matematis Lisan Subjek AAR dalam Pemecahan Masalah Matematika

\section{Tahap Memahami Masalah}

Kutipan wawancara dengan subjek AAR dalam tahap memahami masalah sebagai berikut.

P-01 : Informasi apa saja yang diketahui pada soal tersebut?

SAAR-01 : Rani membeli 4 kemeja dan 2 tas dengan membayar Rp. 630.000. Sedangkan, Andi membeli 1 kemeja dan 3 tas dengan membayar Rp. 520.000

P-02 : Apa yang ditanyakan pada soal tersebut?

SAAR-02 : Ana akan membeli dua jenis barang

P-03 : Apa seluruh informasi yang terdapat dalam soal telah dituliskan dengan lengkap?

SAAR-03 : Sudah

P-04 : Apakah terdapat kesulitan dalam menuliskan informasi yang terdapat pada soal?

SAAR-04 : Tidak terdapat kesulitan sama sekali

Berdasarkan kutipan hasil wawancara tersebut maka dapat dianalisis komunikasi matematis lisan subjek 
AAR dalam tahap memahami masalah sebagai berikut.

\section{Keakuratan}

Subjek AAR mengucapkan hal-hal yang diketahui pada soal dengan tepat. Hal tersebut ditunjukkan pada kode percakapan P-01 dengan SAAR-01. Akan tetapi, subjek AAR kurang tepat dalam menjelaskan hal yang ditanyakan pada soal. Ditunjukkan pada kode percakapan P-02 dengan SAAR-02.

\section{Kelengkapan}

Subjek AAR telah mengucapkan seluruh informasi yang diketahui pada soal tersebut dengan lengkap. Akan tetapi, subjek AAR belum cukup lengkap dalam menjelaskan hal-hal yang ditanyakan pada soal. Ditunjukkan pada kode SAAR-02.

\section{Kelancaran}

Subjek AAR telah mengucapkan hal-hal yang diketahui dan ditanyakan dengan lancar tanpa tersendat-sendat.

\section{Tahap Menyusun Rencana Penyelesaian Masalah}

Kutipan wawancara dengan subjek AAR dalam tahap menyusun rencana penyelesaian masalah sebagai berikut.

$\begin{array}{lll}\text { P-05 : } & \begin{array}{l}\text { Langkah awal apa yang dilakukan untuk } \\ \text { menyelesaikan soal tersebut? }\end{array} \\ \text { SAAR-05 : } \begin{array}{l}\text { Menggunakan metode eliminasi untuk } \\ \text { menentukan nilai variabel y atau harga dari }\end{array} & \begin{array}{l}\text { sebuah tas } \\ \text { P-06 : }\end{array} \\ \text { Setelah menggunakan metode eliminasi kemudian } \\ \text { SAAR-06 : } \begin{array}{l}\text { Menentukan nilai variabel x atau harga dari satu } \\ \text { buah kemeja }\end{array} \\ \text { P-07 : } \quad \begin{array}{l}\text { Selain menggunakan metode eliminasi, apakah } \\ \text { terdapat metode lain untuk menyelesaikan soal } \\ \text { tersebut? }\end{array} \\ \text { SAAR-07 : } \begin{array}{l}\text { Menggunakan metode substitusi } \\ \text { P-08 : Apakah terdapat kesulitan dalam menyusun } \\ \text { rencana untuk penyelesaian soal tersebut? }\end{array} \\ \text { SAAR-08 : Tidak terdapat kesulitan karena sudah belajar }\end{array}$

Berdasarkan kutipan hasil wawancara tersebut maka dapat dianalisis komunikasi matematis lisan subjek AAR dalam tahap menyusun rencana penyelesaian masalah sebagai berikut.

\section{Keakuratan}

Subjek AAR telah mengucapkan metode apa yang digunakan untuk penyelesaian masalah tersebut dengan tepat. Subjek AAR juga telah memodelkan harga satu buah tas dengan variabel y dan harga satu buah kemeja dengan variabel $x$. Hal tersebut ditunjukkan pada kode percakapan P-05, SAAR-05, P-06, SAAR-06, P-07, SAAR-07.

\section{Kelengkapan}

Subjek AAR telah mengucapkan seluruh rencana penyelesaian masalah dengan lengkap. Subjek juga telah menjelaskan metode apa yang digunakan untuk menyelesaikan masalah tersebut. Ditunjukkan pada kode percakapan P-05, SAAR-05, P-06, SAAR-06, P-07, SAAR-07.

\section{Kelancaran}

Subjek AAR telah mengucapkan seluruh rencana penyelesaian masalah tersebut dengan lancar tanpa tersendat-sendat.

\section{Tahap Menyelesaikan Masalah}

Kutipan wawancara dengan subjek AAR dalam tahap menyelesaikan masalah sebagai berikut.

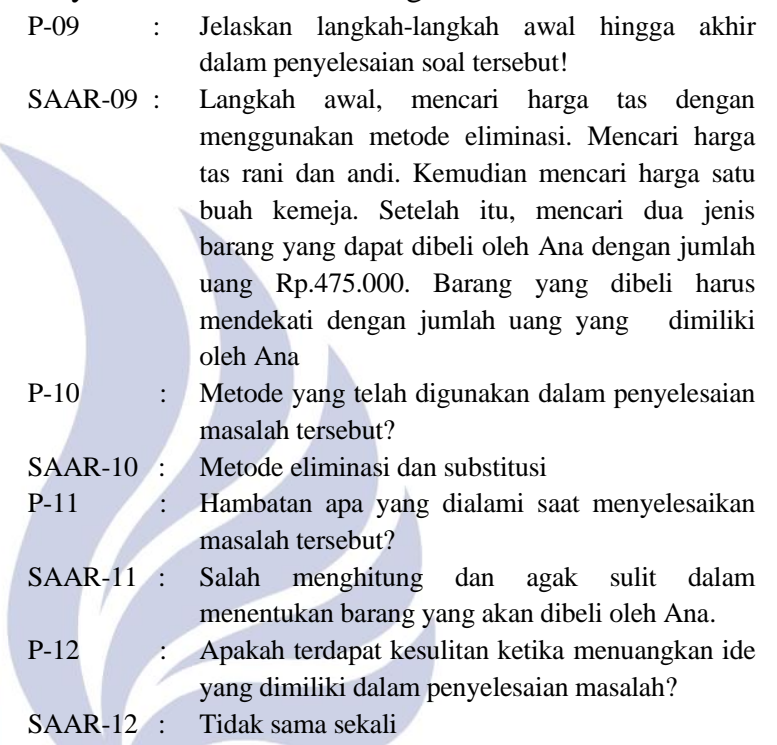

Berdasarkan kutipan hasil wawancara tersebut maka dapat dianalisis komunikasi matematis lisan subjek AAR dalam tahap menyelesaikan masalah sebagai berikut.

\section{Keakuratan}

Langkah awal yang dilakukan subjek AAR adalah dengan menggunakan metode eliminasi untuk menentukan harga dari satu buah tas. Kemudian mencari harga satu buah kemeja. Setelah diperoleh harga satu buah kemeja dan tas, maka subjek AAR menentukan barang yang dapat dibeli oleh Ana dengan uang Rp 475.000. Berdasarkan uraian diatas maka subjek AAR dapat menjelaskan tahap-tahap penyelesaian masalah dengan tepat hanya saja terdapat satu pernyataan yang kurang tepat pada kode SAAR-09 yang menyebutkan "Mencari harga tas Rani dan Andi". Pernyataan tersebut tidak dibutuhkan untuk penyelesaian masalah tersebut.

\section{Kelengkapan}

Subjek AAR telah menjelaskan langkah-langkah penyelesaian masalah, yaitu dengan menggunakan metode eliminasi untuk menentukan harga satu buah tas. Setelah itu menentukan harga satu buah kemeja. Kemudian subjek AAR menentukan dua jenis barang sebanyak-banyaknya yang dapat dibeli oleh Ana. Pada tahap ini terdapat beberapa kekurangan pada 
subjek AAR seperti tidak menjelaskan mengenai persamaan yang diperoleh dari soal. Kemudian subjek AAR tidak menjelaskan bagaimana cara menentukan nilai variabel $\mathrm{x}$ atau harga dari sebuah kemeja sehingga dari beberapa uraian diatas dapat disimpulkan subjek AAR belum cukup lengkap dalam menjelaskan penyelesaian masalah tersebut.

\section{Kelancaran}

Subjek AAR menjelaskan langkah-langkah penyelesaian masalah dengan lancar tanpa tersendatsendat.

\section{Tahap Memeriksa Kembali}

Kutipan wawancara dengan subjek AAR dalam tahap memeriksa kembali sebagai berikut.

P-13 : Sudah yakin jika pekerjaannya telah diselesaikan dengan baik?

SAAR-13 : Yakin

P-14 : Kesimpulan apa yang diperoleh setelah menyelesaikan soal tersebut?

SAAR-14 : Soal yang telah diselesaikan tersebut merupakan materi SPLDV atau Sistem Persamaan Linear Dua Variabel. Penyelesainnya dengan menggunakan metode eliminasi dan substitusi.

Berdasarkan kutipan hasil wawancara tersebut maka dapat dianalisis kemampuan komunikasi matematis subjek AAR dalam tahap memeriksa kembali sebagai berikut.

\section{Keakuratan}

Subjek AAR pada tahap memeriksa kembali telah mengucapkan kesimpulan dengan tepat. Hal tersebut ditunjukkan pada kode SAAR-14.

\section{Kelancaran}

Subjek AAR telah mengucapkan kesimpulan tersebut dengan lancar dan tanpa tersendat-sendat.

2. Hasil dan Analisis Data Komunikasi Matematis Lisan Subjek FK dalam Pemecahan Masalah Matematika

Tahap Memahami Masalah

Kutipan wawancara dengan subjek FK dalam tahap memahami masalah sebagai berikut.
P-01 : Dari pekerjaan yang telah diselesaikan maka informasi apa saja yang diperoleh dari soal?
SFK-01 : Jika Ana mempunyai uang Rp 475.000 dan akan membeli dua jenis barang sebanyak-banyaknya maka barang apa saja yang dapat dibeli oleh Ana
P-02 : Kemudian yang diketahui pada soal tersebut?
SFK-02 : Rani, Andi, dan Ana membeli kemeja dan tas di toko yang sama. Rani membeli 4 kemeja dan 2 tas dengan membayar Rp 630.000. Sedangkan, Andi membeli 1 kemeja dan 3 tas dengan membayar Rp 520.000
P-03 : Sebutkan lagi yang menjadi pertanyaan dalam soal tersebut?
SFK-03 : Ana mempunyai uang Rp 475.000 dan akan membeli dua jenis barang sebanyak-banyaknya maka barang apa saja yang akan dibeli oleh Ana

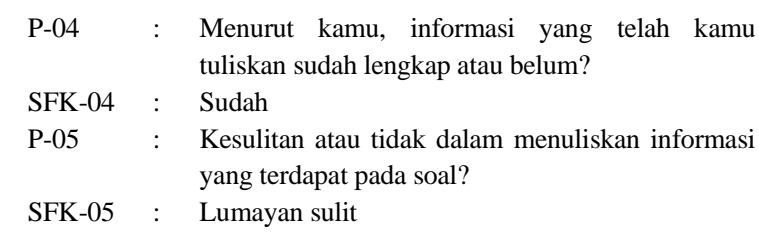

Berdasarkan kutipan hasil wawancara tersebut maka dapat dianalisis kemampuan komunikasi matematis subjek FK dalam tahap memahami masalah sebagai berikut.

\section{Keakuratan}

Subjek AAR telah menjelaskan seluruh informasi yang diketahui dan ditanyakan dengan tepat. Hal tersebut ditunjukkan pada kode percakapan P-01, SFK-01, P-02, SFK-02, P-03, dan SFK-03.

\section{Kelengkapan}

Subjek AAR telah menjelaskan seluruh informasi yang diketahui dan ditanyakan pada soal dengan lengkap. Hal tersebut ditunjukkan pada kode percakapan P-01, SFK-01, P-02, SFK-02, P-03, dan SFK-03.

\section{Kelancaran}

Subjek AAR telah menjelaskan seluruh informasi pada tahap ini dengan lancar dan tidak tersendatsendat.

Tahap Menyusun Rencana Penyelesaian Masalah Kutipan wawancara dengan subjek FK dalam tahap menyusun rencana penyelesaian masalah sebagai berikut.

P-06 : Langkah awal apa yang digunakan untuk menyelesaikan masalah ini?

SFK-06 : Menuliskan yang diketahui dan ditanya

P-07 : Metode apa yang digunakan untuk menyelesaikan masalah?

SFK-07 : Variabel

P-08 : Metode yang telah kamu gunakan namanya metode apa?

SFK-08 : Metode eliminasi

P-09 : Apakah ada langkah lain untuk menyelesaikan masalah ini?

SFK-09 : Tidak tahu

P-10 : Konsep apa yang terdapat dalam masalah 1 Ui tersebut?

SFK-10 : Tidak tahu

P-11 : Sulit atau tidak dalam menyusun rencana awal penyelesaian masalah?

SFK-11 : Tidak, tapi kesulitan di akhir menyelesaian soal itu

Berdasarkan kutipan hasil wawancara tersebut maka dapat dianalisis kemampuan komunikasi matematis subjek FK dalam tahap menyusun rencana penyelesaian masalah sebagai berikut.

\section{Keakuratan}

Subjek FK telah menjelaskan rencana penyelesaian masalah tersebut belum cukup tepat. Karena pada percakapan tersebut terlihat bahwa subjek FK tidak dapat menjelaskan beberapa pertanyaan yang 
diajukan oleh peneliti. Hal tersebut ditunjukkan pada kode percakapan P-07, SFK-07,P-09, SFK-09, P-10, dan SFK-10.

\section{Kelengkapan}

Subjek FK belum cukup lengkap dalam menjelaskan rencana penyelesaian masalah. Karena subjek FK tidak dapat menyebutkan metode apa yang dapat digunakan selain metode eliminasi. Hal tersebut ditunjukkan pada kode percakapan P-08 dan SFK-08. Subjek FK juga tidak menjelaskan persamaanpersamaan yang diperoleh dari soal.

\section{Kelancaran}

Subjek FK belum cukup lancar pada tahap menyusun rencana penyelesaian masalah. Hal tersebut dikarenakan subjek FK tidak dapat menjawab beberapa pertanyaan yang diajukan oleh peneliti. Seperti pada kode percakapan P-07 dan SFK-07, dalam percakapan tersebut peneliti bertanya mengenai metode apa yang digunakan namun subjek menjawab dengan kata "variabel".

\section{Tahap Menyelesaikan Masalah}

Kutipan wawancara dengan subjek FK dalam tahap menyelesaikan masalah sebagai berikut.

\begin{tabular}{|c|c|c|}
\hline P-12 & : & $\begin{array}{l}\text { Jelaskan dari awal langkah-langkahnya saja dalam } \\
\text { menyelesaikan masalah ini? }\end{array}$ \\
\hline SFK-12 & : & $\begin{array}{l}4 \mathrm{x}+2 \mathrm{y}=630.000 \text {. Bawahnya } \mathrm{x}+3 \mathrm{y}=520.000 \\
\text { kemudian digaris dikali satu dan empat. Empat } \\
\text { dikali satu, dua dikali satu dan enam ratus tiga } \\
\text { puluh ribu dikali satu. Dibawahnya empat kali } \\
\text { satu, empat kali tiga dan lima ratus dua puluh ribu } \\
\text { dikali empat. Kemudian hasilnya seribu empat } \\
\text { ratus lima puluh dan sebelahnya negatif sepuluh y. } \\
\text { Seribu empat ratus lima puluh dibagi sepuluh } \\
\text { sama dengan y seratus empat lima. Variabel y } \\
\text { sebagai harga dari sebuah tas. }\end{array}$ \\
\hline P-13 & : & $\begin{array}{l}\text { Setelah mencari harga tas, kemudian mencari } \\
\text { harga apa? }\end{array}$ \\
\hline SFK-13 & : & $\begin{array}{l}\text { Mencari harga kemeja, } 4 x+y 145=290 . \text { Empat } \\
\text { kemeja tiga ratus empat puluh maka satu kemeja } \\
\text { delapan lima ribu. }\end{array}$ \\
\hline
\end{tabular}

$\begin{array}{lll}\text { P-14 } & \text { Setelah itu? } \\ \text { SFK-14 : } & \text { Ana mempunyai uang Rp } 475.000 \text { dan akan }\end{array}$

SFK-14 : Ana mempunyai uang Rp 475.000 dan akan
membeli dua jenis barang sebanyak-banyaknya maka barang apa yang dapat dibeli oleh Ana. Ana membeli dua kemeja dan dua tas memiliki kembalian lima belas ribu.

P-15 : Apa alasannya menggunakan metode eliminasi?

SFK-15 : Lebih gampang

P-16 : Ada atau tidak kesulitan atau hambatan dalam menyelesaikan masalah?

SFK-16 : Ada, mencari harga kemeja. Karena sulit menghitung.

P-17 : Ada kesulitan dalam menuangkan ide?

SFK-17 : Iya, lumayan sulit

Berdasarkan kutipan hasil wawancara tersebut maka dapat dianalisis kemampuan komunikasi matematis subjek FK dalam tahap menyelesaikan masalah sebagai berikut.

\section{Keakuratan}

Subjek FK telah menjelaskan langkah-langkah penyelesaian masalah dengan cukup tepat. Subjek FK telah menjelaskan penggunaan metode eliminasi untuk menentukan nilai variabel y atau harga dari satu buah tas. Hal tersebut ditunjukkan pada kode percakapan SFK-12. Kemudian subjek FK mencari harga satu buah kemeja. Ditunjukkan pada kode percakapan SFK-13. Setelah itu subjek FK menentukan dua jenis barang yang akan dibeli oleh Ana, yaitu dua tas dan dua kemeja. Ditunjukkan pada kode percakapan SFK-14.

\section{Kelengkapan}

Subjek FK menjelaskan langkah-langkah penyelesaian masalah belum cukup lengkap. Hal tersebut dikarenakan subjek FK tidak memaparkan cara yang digunakan untuk menentukan harga dari satu buah kemeja. Hal tersebut ditunjukkan pada kode percakapan SFK-13 yang hanya menunjukkan sebuah persamaan dan hasilnya saja. Meskipun demikian, perhitungan subjek FK telah tepat dalam menentukan harga satu buah kemeja.

\section{Kelancaran}

Subjek FK menjelaskan langkah-langkah penyelesaian masalah tersebut dengan lancar dan tanpa tersendat-sendat.

\section{Tahap Memeriksa Kembali}

Kutipan wawancara dengan subjek FK dalam tahap memeriksa kembali sebagai berikut.

$\begin{array}{lll}\text { P-18 } & \text { Menurut kamu, pekerjaan yang telah kamu } \\ & \text { selesaikan sudah benar atau belum? } & \\ \text { SFK-18 } & : & \text { Menurutku benar } \\ \text { P-19 } & : & \text { Sudah diperiksa lagi ya? } \\ \text { SFK-19 }: & \text { Sudah } \\ \text { P-20 } & : \begin{array}{l}\text { Kesimpulan apa yang diperoleh setelah } \\ \text { mengerjakan soal ini? }\end{array} \\ \text { SFK-20 : } & \begin{array}{l}\text { Metode yang digunakan eliminasi, kemudian } \\ \text { mencari harga kemeja. }\end{array} \\ \text { P-21 }: \text { Soal tersebut membahas mengenai materi apa? } \\ \text { SFK-21 : } \text { Materi SPLDV }\end{array}$
Berdasarkan kutipan hasil wawancara tersebut maka dapat dianalisis kemampuan komunikasi matematis subjek FK dalam tahap memeriksa kembali sebagai berikut.

\section{Keakuratan}

Subjek FK telah mengucapkan kesimpulan tersebut dengan cukup tepat. Dikatakan cukup tepat karena subjek FK hanya menyebutkan satu metode saja yang digunakan untuk penyelesaian masalah Sistem Persamaan Linear Dua Variabel (SPLDV) tersebut, yaitu metode eliminasi. Subjek FK tidak menyebutkan istilah atau nama metode substitusi untuk penyelesaian masalah tersebut. Hal tersebut 
ditunjukkan pada kode P-20, FK-20, P-21, dan FK21.

\section{Kelancaran}

Subjek FK mengucapkan kesimpulan tersebut dengan lancar dan tanpa tersendat-sendat.

\section{KESIMPULAN DAN SARAN \\ Kesimpulan}

Berdasarkan hasil penelitian dan pembahasan maka dapat ditarik kesimpulan mengenai kemampuan komunikasi matematis subjek AAR dan FK sebagai berikut.

Tabel 7. Kemampuan Komunikasi Matematis Tulis

\begin{tabular}{|c|c|c|c|c|c|}
\hline \multirow{2}{*}{$\begin{array}{l}\text { Kode } \\
\text { Nama }\end{array}$} & \multirow{2}{*}{$\begin{array}{c}\text { Tahap } \\
\text { Pemecahan } \\
\text { Masalah }\end{array}$} & \multirow{2}{*}{$\begin{array}{c}\text { Informasi yang } \\
\text { Disampaikan }\end{array}$} & \multicolumn{3}{|c|}{ Aspek Komunikasi Matematis Tulis } \\
\hline & & & Keakuratan & Kelengkapan & Kelancaran \\
\hline \multirow{5}{*}{ AAR } & $\begin{array}{l}\text { Memahami } \\
\text { Masalah }\end{array}$ & $\begin{array}{l}\text { Hal-hal yang } \\
\text { diketahui dan } \\
\text { ditanya }\end{array}$ & Akurat & Lengkap & Lancar \\
\hline & \multirow{2}{*}{$\begin{array}{l}\text { Menyusun } \\
\text { Rencana } \\
\text { Penyelesaian } \\
\text { Masalah }\end{array}$} & $\begin{array}{l}\text { Strategi penyelesaian } \\
\text { masalah menurut } \\
\text { kaidah matematika }\end{array}$ & Akurat & $\begin{array}{c}\text { Tidak } \\
\text { Lengkap }\end{array}$ & Lancar \\
\hline & & $\begin{array}{l}\text { Istilah atau notasi } \\
\text { matematika menurut } \\
\text { kaidah matematika }\end{array}$ & Akurat & $\begin{array}{c}\text { Tidak } \\
\text { Lengkap }\end{array}$ & Lancar \\
\hline & $\begin{array}{l}\text { Menyelesaikan } \\
\text { Masalah }\end{array}$ & $\begin{array}{l}\text { Langkah-langkah } \\
\text { penyelesaian } \\
\text { masalah dan } \\
\text { perhitungan yang } \\
\text { telah dilakukan }\end{array}$ & Akurat & $\begin{array}{c}\text { Tidak } \\
\text { Lengkap }\end{array}$ & Lancar \\
\hline & $\begin{array}{l}\text { Memeriksa } \\
\text { Kembali }\end{array}$ & Kesimpulan & Akurat & - & Lancar \\
\hline \multirow{5}{*}{ FK } & $\begin{array}{l}\text { Memahami } \\
\text { Masalah }\end{array}$ & $\begin{array}{l}\text { Hal-hal yang } \\
\text { diketahui dan } \\
\text { ditanya }\end{array}$ & $\begin{array}{l}\text { Tidak } \\
\text { Akurat }\end{array}$ & $\begin{array}{c}\text { Tidak } \\
\text { Lengkap }\end{array}$ & Lancar \\
\hline & \multirow{2}{*}{$\begin{array}{l}\text { Menyusun } \\
\text { Rencana } \\
\text { Penyelesaian } \\
\text { Masalah }\end{array}$} & $\begin{array}{l}\text { Strategi penyelesaian } \\
\text { masalah menurut } \\
\text { kaidah matematika }\end{array}$ & Akurat & $\begin{array}{l}\text { Tidak } \\
\text { Lengkap }\end{array}$ & Lancar \\
\hline & & $\begin{array}{l}\text { Istilah atau notasi } \\
\text { matematika menurut } \\
\text { kaidah matematika }\end{array}$ & $\begin{array}{l}\text { Tidak } \\
\text { Akurat }\end{array}$ & $\begin{array}{c}\text { Tidak } \\
\text { Lengkap }\end{array}$ & $\begin{array}{l}\text { Tidak } \\
\text { Lancar }\end{array}$ \\
\hline & $\begin{array}{l}\text { Menyelesaikan } \\
\text { Masalah }\end{array}$ & $\begin{array}{l}\text { Langkah-langkah } \\
\text { penyelesaian } \\
\text { masalah dan } \\
\text { perhitungan yang } \\
\text { telah dilakukan }\end{array}$ & Akurat & $\begin{array}{c}\text { Tidak } \\
\text { Lengkap }\end{array}$ & $\begin{array}{l}\text { Tidak } \\
\text { Lancar }\end{array}$ \\
\hline & $\begin{array}{l}\text { Memeriksa } \\
\text { Kembali }\end{array}$ & Kesimpulan & $\begin{array}{l}\text { Tidak } \\
\text { Akurat }\end{array}$ & - & $\begin{array}{l}\text { Tidak } \\
\text { Lancar }\end{array}$ \\
\hline
\end{tabular}

Pada tahap memahami masalah subjek AAR menuliskan hal-hal yang diketahui dan ditanyakan dengan akurat, lengkap dan lancar. Kemudian pada tahap menyusun rencana penyelesaian masalah subjek AAR menuliskan strategi penyelesaian masalah dan menuliskan istilah atau notasi matematika dengan akurat dan lancar namun tidak lengkap. Pada tahap menyelesaikan masalah subjek AAR telah menuliskan langkah-langkah penyelesaian masalah dan perhitungan dengan akurat, lancar namun tidak lengkap. Pada tahap yang terakhir, yaitu tahap memeriksa kembali subjek AAR telah menuliskan kesimpulan secara akurat dan lancar.

Sedangkan subjek FK dalam tahap memahami masalah telah menuliskan hal-hal yang diketahui dan ditanyakan dengan lancar, namun tidak akurat dan tidak lengkap. Pada tahap menyusun rencana penyelesaian masalah subjek FK telah menuliskan strategi penyelesaian masalah dengan akurat dan lancar namun tidak lengkap, sedangkan dalam menuliskan istilah atau notasi matematika subjek FK tidak akurat, tidak lengkap, dan juga tidak lancar. Kemudian pada tahap menyelesaikan masalah subjek FK telah menuliskan langkah-langkah penyelesaian masalah dan perhitungan dengan akurat namun tidak lengkap dan tidak lancar. Pada tahap yang terakhir, yaitu tahap memeriksa kembali subjek FK telah menuliskan kesimpulan dengan tidak akurat dan tidak lancar.

Tabel 8. Kemampuan Komunikasi Matematis Lisan

\begin{tabular}{|c|c|c|c|c|c|}
\hline \multirow{2}{*}{$\begin{array}{l}\text { Kode } \\
\text { Nama }\end{array}$} & \multirow{2}{*}{$\begin{array}{l}\text { Tahap } \\
\text { Pemecahan } \\
\text { Masalah }\end{array}$} & \multirow{2}{*}{$\begin{array}{l}\text { Informasi yang } \\
\text { Disampaikan }\end{array}$} & \multicolumn{3}{|c|}{ Aspek Komunikasi Matematis Lisan } \\
\hline & & & Keakuratan & Kelengkapan & Kelancarar \\
\hline \multirow{5}{*}{ AAR } & $\begin{array}{l}\text { Memahami } \\
\text { Masalah }\end{array}$ & $\begin{array}{l}\text { Hal-hal yang } \\
\text { diketahui dan } \\
\text { ditanya }\end{array}$ & Akurat & $\begin{array}{c}\text { Tidak } \\
\text { Lengkap }\end{array}$ & Lancar \\
\hline & \multirow{2}{*}{$\begin{array}{l}\text { Menyusun } \\
\text { Rencana } \\
\text { Penyelesaian } \\
\text { Masalah }\end{array}$} & $\begin{array}{l}\text { Strategi penyelesaian } \\
\text { masalah menurut } \\
\text { kaidah matematika }\end{array}$ & Akurat & Lengkap & Lancar \\
\hline & & $\begin{array}{l}\text { Istilah atau notasi } \\
\text { matematika menurut } \\
\text { kaidah matematika }\end{array}$ & Akurat & Lengkap & Lancar \\
\hline & $\begin{array}{l}\text { Menyelesaikan } \\
\text { Masalah }\end{array}$ & $\begin{array}{l}\text { Langkah-langkah } \\
\text { penyelesaian } \\
\text { masalah dan } \\
\text { perhitungan yang } \\
\text { telah dilakukan }\end{array}$ & Akurat & $\begin{array}{c}\text { Tidak } \\
\text { Lengkap }\end{array}$ & Lancar \\
\hline & $\begin{array}{l}\text { Memeriksa } \\
\text { Kembali }\end{array}$ & Kesimpulan & Akurat & - & Lancar \\
\hline \multirow{5}{*}{ FK } & $\begin{array}{l}\text { Memahami } \\
\text { Masalah }\end{array}$ & $\begin{array}{l}\text { Hal-hal yang } \\
\text { diketahui dan } \\
\text { ditanya }\end{array}$ & Akurat & Lengkap & Lancar \\
\hline & \multirow{2}{*}{$\begin{array}{l}\text { Menyusun } \\
\text { Rencana } \\
\text { Penyelesaian } \\
\text { Masalah }\end{array}$} & $\begin{array}{l}\text { Strategi penyelesaian } \\
\text { masalah menurut } \\
\text { kaidah matematika }\end{array}$ & $\begin{array}{c}\text { Tidak } \\
\text { Akurat }\end{array}$ & $\begin{array}{c}\text { Tidak } \\
\text { Lengkap }\end{array}$ & $\begin{array}{l}\text { Tidak } \\
\text { Lancar }\end{array}$ \\
\hline & & $\begin{array}{l}\text { Istilah atau notasi } \\
\text { matematika menurut } \\
\text { kaidah matematika }\end{array}$ & Akurat & $\begin{array}{c}\text { Tidak } \\
\text { Lengkap }\end{array}$ & $\begin{array}{l}\text { Tidak } \\
\text { Lancar }\end{array}$ \\
\hline & $\begin{array}{l}\text { Menyelesaikan } \\
\text { Masalah }\end{array}$ & $\begin{array}{l}\text { Langkah-langkah } \\
\text { penyelesaian } \\
\text { masalah dan } \\
\text { perhitungan yang } \\
\text { telah dilakukan }\end{array}$ & Akurat & $\begin{array}{c}\text { Tidak } \\
\text { Lengkap }\end{array}$ & Lancar \\
\hline & $\begin{array}{l}\text { Memeriksa } \\
\text { Kembali }\end{array}$ & Kesimpulan & $\begin{array}{l}\text { Tidak } \\
\text { Akurat }\end{array}$ & - & Lancar \\
\hline
\end{tabular}

Pada tahap memahami masalah subjek AAR telah menjelaskan hal-hal yang diketahui dan ditanyakan dengan akurat, lancar namun tidak lengkap. Sedangkan pada tahap menyusun rencana penyelesaian masalah subjek AAR telah menjelaskan strategi penyelesaian masalah dan menuliskan istilah atau notasi matematika dengan akurat, lengkap dan lancar. Pada tahap menyelesaikan masalah subjek AAR telah menjelaskan langkah-langkah penyelesaian masalah dan perhitungan dengan akurat, lancar namun tidak lengkap. Kemudian pada tahap yang terakhir yakni tahap memeriksa kembali subjek AAR telah menuliskan kesimpulan dengan akurat dan lancar.

Pada tahap memahami masalah subjek FK telah menuliskan hal-hal yang diketahui dan ditanyakan dengan lancar, akurat dan lengkap. Pada tahap menyusun rencana penyelesaian masalah subjek FK telah menuliskan strategi penyelesaian masalah dengan akurat, lengkap dan lancar, sedangkan dalam menuliskan istilah atau notasi matematika subjek FK telah akurat namun tidak lengkap dan tidak lancar. Kemudian pada tahap menyelesaikan masalah subjek FK telah menuliskan langkah-langkah penyelesaian masalah dan perhitungan dengan akurat dan lancar namun tidak lengkap. Pada tahap terakhir yakni 
memeriksa kembali subjek FK telah menuliskan kesimpulan dengan lancar namun tidak lengkap.

\section{Saran}

Siswa perlu dibiasakan untuk membangun ide-ide atau gagasan matematis yang dimiliki dalam menyelesaikan masalah matematika. Hal tersebut dimaksudkan agar siswa menjadi lebih terbiasa melibatkan keterampilan atau kemampuan komunikasi matematis yang dimiliki dalam pemecahan masalah matematika. Oleh karena itu, penting bagi guru untuk selalu mengeksplor ide atau gagasan yang dimiliki para siswa guna memudahkan siswa dalam menyelesaikan setiap permasalahan matematika yang dihadapi. Meskipun demikian, banyak kekurangan dalam penelitian ini sehingga diharapkan peneliti lain dapat mengkaji lebih lanjut mengenai kemampuan komunikasi matematis siswa ditinjau dari sisi lain.

\section{DAFTAR PUSTAKA}

Abdurrahman, M. 2003. Pendidikan Bagi Anak Berkesulitan Belajar. Jakarta: Rineka Cipta.

Azwar, S. 2015.Penyusunan Skala Psikologi (Edisi 2). Yogyakarta: Pustaka Pelajar.

Cahyono, Budi. 2017. Analisis Keterampilan Berfikir Kritis dalam Memecahkan Masalah Ditinjau Perbedaan Gender. Jurnal Aksioma. 8(1).

Dewi, I. 2009. Profil Komunikasi Matematis Mahasiswa Calon Guru Ditinjau dari Perbedaan Jenis Kelamin. Disertasi tidak dipublikasikan pasca sarjana Universitas Negeri Surabaya.

Lestari. 2013. Himpunan Lengkap Undang-Undang Sisdiknas dan Sertifikasi Guru (cetakan ke-1). Jogjakarta: Buku Biru.

Meisya, S., Suhandri, \& Nufus, H. 2018.Pengembangan Lembar Kerja Siswa Berbasis Model Eliciting Activities untuk Memfasilitasi Kemampuan Komunikasi Matematis Siswa Sekolah Menengah Pertama.Juring (Journal for Research in Mathematics Learning), 1(1),33-42.

Miles,M.B, Huberman,A.M, dan Saldana, J. 2014. Qualitative Data Analysis, A. Methods Sourcebook, Edition 3. USA: Sage Publications. Terjemahan Tjetjep Rohindi Rohidi, UI-Press.

Moleong, Lexy J. 2016. Metodologi Penelitian Kualitatif (cetakan ke-35). Bandung: PT. Remaja Rosda Karya.

National Council of Teacher of Mathematics. 2000. Principles and Standards for School Mathematics.

OECD. 2016. PISA 2015 Result in Focus. OECD Publishing.

OECD. 2018. PISA 2018 Insights and Interpretations. OECD Publishing.
Puspitasari, E., Yusmin, E., \& Nursangaji, A. 2015. Analisis Kesulitan Siswa Menyelesaikan Soal Cerita Materi Sistem Persamaan Linear Dua Variabel DI SMP. Jurnal Pendidikan dan Pembelajaran, 4(5)

Rakhmat, J. 2000. Psikologi Agama. Jakarta: Raja Grafindo Persada.

Rais, D. 2017. Pengembangan Perangkat Pembelajaran Matematika Berbasis Missouri Mathematics Project untuk Meningkatkan Kemampuan Komunikasi Matematis Siswa Kelas X SMA/MA. JNPM (Jurnal Nasional Pendidikan Matematika) Vol. 1(2), Hal.189205.

Semiawan, Conny R. 2010 Metode Penelitian Kualitatif Jakarta: Grasindo.

Schmitt, D.P., \& Allik, J. 2005. Simultaneous administration of the Rosenberg Self-Esteem Scale in 53 nations: Exploring the universal and culture specific features of global self-esteem. Journal of Personality and Social Psychology, 89(4), 623-642. doi: 10.1037/0022-3514.89.4.623

Sidik, A., Ramlah, \& Utami, M. R. 2017. Hubungan Antara Self-Confidence dengan Kemampuan Komunikasi Matematis Siswa SMP. Prosiding Seminar Nasional Matematika Dan Pendidikan Matematika (SESIOMADIKA), 222-226.

Sugiyono. 2013. Metode Penelitian Pendidikan Pendekatan Kuantitatif, Kualitatif dan R\&D. Bandung: Alfabeta.

Tandiling, E. 2012. "Pengembangan Instrumen untuk Mengukur Kemampuan Komunikasi Matematik, Pemahaman Matematik, dan Self Regulated Learning Siswa dalam Pembelajaran Matematika di Sekolah Menengah Atas". Jurnal Penelitian Pendidikan, 13(1): 24-35.

Wardhani, S. dan Rumiati. 2011. Instrumen Penilaian Hasil Belajar Matematika SMP: Belajar dari PISA dan TIMSS. Yogyakarta: Kemdiknas, P4TK Matematika. 